\title{
PODER MODERAdOR E A CONSTITUIÇÃo da REPÚBLICA FEDERATIVA DO BRASIL
}

\author{
Ricardo Gagliardi*
}

Resumo: Este ensaio teórico visa discutir os fundamentos políticos e jurídicos da possibilidade de "intervenção" de um poder constituído em outro, por meio das Forças Armadas, que agiriam como um poder moderador para restabelecer a ordem democrática. Para tanto, realizou-se uma revisão de literatura especializada sobre textos de teóricos da ciência política, e na sequência, uma revisão sistemática de literatura, incluindo os descritores "poder moderador", "constituição federal" e "forças armadas". Ao final, concluise pela não possibilidade política e jurídica de ação das Forças Armadas como ente encarregado de moderar conflitos entre poderes da República. De outro lado, pode-se compreender que a defesa de tais argumentos de forma institucionalizada pelo Presidente da República evidencia, ao menos, uma maneira de descontentamento dele com o sistema institucional normativo da República brasileira, e/ou um movimento de argumentações retóricas populistas e personalistas, ao mínimo suspeito de suas convicções, em desfavor dos preceitos constitucionais e democráticos.

Palavras-chave: Divisão de Poderes; Poder Moderador; Função Moderadora; Forças Armadas; Poder Político.

\section{Moderating Power ANd The Constitution OF THE FEDERATIVE REPUBLIC OF BRAZIL}

\begin{abstract}
This theoretical essay aims to discuss the political and legal foundations of the possibility of "intervention" by a constituted power in another, through the Armed Forces, which would act as a moderating power to reestablish democratic order. For this purpose, a specialized literature review was carried out on texts by political science theorists, followed by a systematic literature review, including the descriptors "moderating power", "federal constitution" and "armed forces". In the end, it is concluded that there is no political and legal possibility of action by the Armed Forces as an entity in charge of moderating conflicts between the powers of the Republic. On the other hand, it can be understood that the defense of such arguments in an institutionalized way by the President of the Republic evidences, at least, a way of his discontent with the normative institutional system of the Brazilian Republic, and/or a movement of populist and rhetorical arguments, personalists, at the least suspicious of his convictions, in detriment of constitutional and democratic precepts.
\end{abstract}

Keywords: Division of Powers; Moderating Power; Moderating Function; Armed Forces; Political Power.

\footnotetext{
* Doutorando em Direito Constitucional e Teoria Política (PUC-Rio). Mestre em Prestação Jurisdicional e Direitos Humanos (UFT). Especialista em Criminologia (ESMAT). Bacharel em Direito (ITE). Graduado em Ciências Policiais de Segurança e Ordem Pública (APMBB). Juiz de Direito no Estado do Tocantins, Brasil. ORCID - https://orcid.org/0000-0002-6382-925X. Contato: reiricardo2007@gmail.com
} 


\section{El Poder Moderador y la CONSTITUCión de la RePública FEDERATIVA DE BRASIL}

Resumen: Este ensayo teórico tiene como objetivo discutir los fundamentos políticos y legales de la posibilidad de "intervención" de un poder constituido en otro, a través de las Fuerzas Armadas, que actuaría como poder moderador para restablecer el orden democrático. Para ello, se realizó una revisión bibliográfica especializada sobre textos de teóricos de las ciencias políticas, seguida de una revisión bibliográfica sistemática, incluyendo los descriptores "poder moderador", "constitución federal" y "fuerzas armadas". Al final, se concluye que no existe posibilidad política y legal de actuación de las Fuerzas Armadas como entidad encargada de moderar los conflictos entre los poderes de la República. Por otro lado, se puede entender que la defensa de tales argumentos de manera institucionalizada por parte del Presidente de la República evidencia, al menos, una forma de su descontento con el sistema institucional normativo de la República Brasileña, y / o un movimiento de argumentos populistas y retóricos, personalistas, al menos recelosos de sus convicciones, en detrimento de los preceptos constitucionales y democráticos.

Palabras clave: Repartición del Poder; Poder Moderador; Función Moderadora; Fuerzas Armadas; Poder Político.

\section{Introdução}

Por meio de palavras do atual Presidente da República, em reunião divulgada em maio de 2020, relacionou-se a possibilidade de "intervenção" de um poder constituído em outro, por meio das Forças Armadas que agiriam como um poder moderador para restabelecer a ordem. Utilizou o Presidente os seguintes termos: "Nós queremos fazer cumprir o artigo 142 da Constituição. Todo mundo quer fazer cumprir o artigo 142 da Constituição. E, havendo necessidade, qualquer dos Poderes pode, né? Pedir às Forças Armadas que intervenham para restabelecer a ordem no Brasil". Refletiu-se então se o referido artigo constitucional compreenderia a tese de que as forças armadas poderiam agir como um poder moderador, na hipótese de crise entre os poderes da República ${ }^{1}$.

Além de muita discussão na imprensa, no mundo acadêmico, tais argumentações foram levantadas em salas de aula e por meio da publicação de alguns artigos de natureza científica. No Google Acadêmico, por exemplo, com os descritores "poder moderador" e “constituição federal” e "forças armadas", e limitação temporal entre 2020 e 2021, surgiram 12 pesquisas que tratavam direta ou indiretamente dos temas da teoria da exceção, ativismo judicial ou poder moderador.

\footnotetext{
${ }^{1}$ BBC NEWS - BRASIL. O que é o artigo 142 da Constituição, que Bolsonaro citou por intervenção das forças armadas?
} 
Tal tema revela importância especial, tendo em vista que muito se assemelha aos ditames utilizados pelo partido nazista na República de Weimar para promover a sua derrocada, dentro da teoria de constituição de Carl Schmitt ${ }^{2}$, o que gerou um reconhecido ambiente antidemocrático e violador dos direitos humanos. O fato de o Presidente da República e supostos apoiadores, como descrito na mídia, aparentemente invocarem as Forças Armadas, a fim de avaliar ou avalizar eventuais decisões de quaisquer dos poderes da República e assim compor uma espécie de intervenção militar "pontual"3, poderia ser uma evidência apenas retórica de demonstrar força de intimidação, dentro do processo legítimo ou não do exercício da argumentação, e/ou tenderia a um aspecto supostamente voltado a buscar alterar os panoramas político e jurídico do país.

O objetivo deste estudo é analisar se haveria algum fundamento político ou jurídico que pudesse, dentro da racionalidade e razoabilidade, compreender tal hipótese de intervenção moderadora possível no Brasil.

O processo metodológico utilizado para amparar este estudo consistiu em revisão jurídica da Constituição atual e normas correspondentes, por seus fundamentos, da revisão jurídica histórica das demais Constituições brasileiras, da análise de algumas ordens constitucionais em Países ocidentais democráticos, e depois na revisão de algumas teorias da constituição e da ciência política, a partir de Montesquieu. Para complementar, realizouse uma revisão sistemática de literatura ${ }^{4}$, com o fim de integrar as informações, coincidentes ou não, de um conjunto de estudos realizados separadamente sobre determinada temática de forma sistematizada e sintetizar o conhecimento de uma dada área por meio da formulação de uma pergunta, identificação, seleção e avaliação crítica de estudos científicos contidos em bases de dados eletrônicas, e textos indicados como bases de leitura.

A pergunta da pesquisa é: as forças armadas brasileiras poderiam agir como poder moderador na hipótese de dissenso entre os poderes da república? A busca de artigos foi realizada nas bases eletrônicas do Google Scholar, com os descritores: "poder moderador", “constituição federal" e "forças armadas", publicados nos anos de 2020 e 2021, por meio das palavras-chaves acima indicadas, sendo encontrados inicialmente 63 artigos,

\footnotetext{
${ }^{2}$ MAGALHÃES, Vinicius Cunha. O artigo 48 da Constituição de Weimar e a teoria da soberania e do estado de exceção de Carl Schmitt. Conteúdo Jurídico: Brasília-DF, nov. 2017.

${ }^{3}$ MARTINS, Ives Gandra da Silva. Cabe às Forças Armadas moderar os conflitos entre os Poderes. Revista Consultor Jurídico, mai 2020.

${ }^{4}$ SAMPAIO, Rosana Ferreira; MANCINI, Marisa Cotta. Estudos de revisão sistemática: um guia para síntese criteriosa da evidência científica. Revista brasileira de fisioterapia, São Carlos, v. 11, n. 1, jan./fev. 2007, p. 83-89.
} 
permanecendo 12 por possuírem relação temática à presente pesquisa, sendo excluídos os demais.

Para melhor compreensão metodológica acerca das Forças Armadas no contexto da Constituição brasileira vigente, buscou-se isolar os fenômenos relacionados em três perspectivas albergadas em preceitos de naturezas hierárquica e funcional e de conteúdo limitante, a partir de estudos histórico-político e jurídico.

O texto desenvolverá inicialmente o tema pertinente à atual Constituição brasileira e as hipóteses de exceção. Na sequência, explanará sobre as Forças Armadas e o Poder Moderador, em seus diversos recortes, como fenômenos isolados, seguindo para a análise sobre o Poder Moderador e o sistema de divisão de poderes, adotado pela Constituição, buscando reintegrar os fenômenos. Ao final, abordará de forma refletida acerca do suposto alarde anticonstitucional e antidemocrático.

\section{A Constituição brasileira e as hipóteses de exceção}

A República Federativa do Brasil é um Estado Democrático de Direito, constituído por três funções de poder, Legislativo, Executivo e o Judiciário, independentes e harmônicos. Fundamenta-se nos princípios da soberania popular, cidadania, dignidade da pessoa humana, valores sociais do trabalho e da livre iniciativa e no pluralismo político. Declara que todo o poder emana do povo, como fundamento da soberania popular, que o exerce por meio de representantes ou diretamente, nos termos da Constituiçãa ${ }^{5}$.

O objetivo da república democrática é a estabilidade do sistema político, com a alternância de poder dos governos sem violência ${ }^{6}$ para que cumpra seus princípios de justiça ${ }^{7}$, dentro dos preceitos constitucionais. $\mathrm{O}$ mesmo objetivo da estabilidade deve ser observado para as razões descritas por Montesquieu para a separação dos poderes $^{8} \mathrm{e}$ acompanhado por Madison e Hamilton ${ }^{9}$

A norma constitucional possibilitou, no entanto, duas concepções de exceção política, que de alguma forma, alteram em parte as regras previstas em regime de normalidade constitucional. A primeira relaciona-se com situações de fato que violam ou

\footnotetext{
5 BRASIL. Presidência da República. Casa Civil. Subchefia para Assuntos Jurídicos. Constituição da República Federativa do Brasil, 1988.

${ }^{6}$ SCHUMPETER, Joseph Alois. Capitalismo, socialismo e democracia. São Paulo: Editora Unesp Digital, 2017.

${ }^{7}$ RAWLS, John. Justiça como equidade. Uma reformulação. São Paulo: Martins Fontes, 2003.

${ }^{8}$ MONTESQUIEU, Charles. Do espírito das leis. Rio de Janeiro: Editora Pimenta de Melo, 1919.

${ }^{9}$ HAMILTON; MADISON; JAY. O Federalista. Tomo 2. Rio de Janeiro: Typ. Imp. e Const. de J. Villeneuve e Comp., 1840
} 
passam a violar a ordem pública ou a paz social, ou que estabeleça o estado de guerra externa. A segunda concepção se atine aos casos intervenção federal nos Estados, ou seja, atinge a autonomia política dos entes federados. Não se trata aqui de exceções jurídicas, como a prisão provisória.

A primeira concepção trata da declaração de estado de defesa e declaração de estado de sítio, sendo que ambos os institutos possuem regras limitadas e com prazo determinado ou determinável. No primeiro instituto, conforme previsão no art. 136, seu objetivo é preservar ou restabelecer, "em locais restritos e determinados, a ordem pública ou a paz social ameaçadas por grave e iminente instabilidade institucional ou atingidas por calamidades de grandes proporções na natureza", por tempo de até trinta dias, podendo ser prorrogado uma vez, por igual período. O segundo instituto tem previsão no artigo imediatamente seguinte e tem o objetivo de fazer cessar comoção grave de repercussão nacional ou ocorrência de fatos que comprovem a ineficácia de medida tomada durante o estado de defesa, por tempo de até trinta dias, podendo ser prorrogado por várias vezes, por até igual período. A medida de intervenção poderá ocorrer ainda para declaração de estado de guerra ou resposta a agressão armada estrangeira e, nesse caso, pelo tempo suficiente em que perdurar a guerra ou agressão armada estrangeira ${ }^{10}$.

Ambos os institutos de exceção são deliberados por meio de decisões dos poderes executivo e legislativo, podendo ainda, ceder espaço para a decisão jurisdicional se houver lesão ou ameaça de direito em um caso em concreto (art. $5^{\circ}, \mathrm{XXXV}$, da CF). A decisão e o ato do decreto são do Presidente da República nos dois casos. Na primeira hipótese, o chefe do poder executivo, agindo como chefe de Estado, decreta e o Congresso Nacional decide, perdurando os efeitos do decreto até a chancela do Poder Legislativo. Portanto, o controle é posterior a sua decretação. Na segunda, de estado de sítio, o controle é prévio, sendo que o parlamento autoriza o chefe de Estado a decretar ${ }^{11}$.

A Constituição permitiu ainda, nos itens excepcionais descritos em rol de forma exaustiva, uma segunda concepção de exceção, a intervenção da União nos Estados e no Distrito Federal (art. 34 da CF) e dos Estados em seus municípios (art. 35 da CF), por meio de regra estabelecida no texto magno, dispondo sobre hipóteses, legitimidade ativa e autoridade competente. São várias as autoridades, conforme o caso, com poder de iniciativa,

10 BRASIL. Presidência da República. Casa Civil. Subchefia para Assuntos Jurídicos. Constituição da República Federativa do Brasil, 1988, cit.

${ }^{11}$ Idem. 
sendo as autoridades competentes para decretar e executar as medidas de intervenção o Presidente da República (art. 84, X, da CF), se a intervenção for federal, e o Governador de Estado, se a intervenção for estadual ${ }^{12}$.

Nas hipóteses da necessidade da intervenção federal com o fim de prover a execução de lei federal, e assegurar a observância dos princípios constitucionais sensíveis como, a forma republicana, o sistema representativo e o regime democrático, os direitos da pessoa humana, a autonomia municipal, e a prestação de contas da administração pública, direta e indireta, e a aplicação do mínimo exigida da receita resultante de impostos estaduais, compreendida a proveniente de transferências, na manutenção e desenvolvimento do ensino e nas ações e serviços públicos de saúde, a iniciativa é do Procurador-Geral da República, chefe do Ministério Público Federal, e decisão do Supremo Tribunal Federal que requisita o ato do Presidente da República ${ }^{13}$. No caso de desobediência, à ordem ou decisão judiciária, a iniciativa e a decisão são do Supremo Tribunal Federal, Superior Tribunal de Justiça ou do Tribunal Superior Eleitoral, que requisitam a medida de intervenção ao Presidente da República.

Assevere-se que em nenhum dos institutos e exceções há previsão de invasão de competência ou de atribuições entre os poderes da República.

\section{As Forças Armadas e o Poder Moderador}

Nenhum dispositivo da Constituição trata explicitamente do instituto do poder moderador. A questão de fundo inicial a se desvendar é se implicitamente o poder moderador existiria na atual conjuntura brasileira e se poderia ser exercido pelas Forças Armadas. $\mathrm{O}$ art. 142 da Constituição encontra-se previsto no capítulo que trata das forças armadas e estabelece, in verbis:

Art. 142. As Forças Armadas, constituídas pela Marinha, pelo Exército e pela Aeronáutica, são instituições nacionais permanentes e regulares, organizadas com base na hierarquia e na disciplina, sob a autoridade suprema do Presidente da República, e destinam-se à defesa da Pátria, à garantia dos poderes constitucionais e, por iniciativa de qualquer destes, da lei e da ordem.

Três perspectivas de análises merecem argumentação inicial no contexto do estudo institucional das Forças Armadas, para se buscar a compreensão do poder e da função moderadora. Para tanto, para fins metodológicos, para buscar o melhor detalhamento, isola-

\footnotetext{
12 Idem.

${ }^{13}$ Idem.
} 
se os preceitos de naturezas hierárquica e funcional e de conteúdo limitante, a partir de estudos histórico-político e jurídico.

\subsection{Perspectiva do preceito de natureza hierárquica}

A primeira perspectiva, relacionada à natureza hierárquica, confirma que o Presidente da República é a autoridade superior das Forças Armadas. Todas as Constituições brasileiras republicanas $(1891,1934,1937,1946,1967,1988)$ ditaram que as Forças Armadas estavam imbricadas constitucionalmente à chefia suprema do Presidente da República, seja na parte que tratava especificamente das Forças Armadas seja nas atribuições do Presidente da República ou do Poder Executivo.

Segue a mesma técnica de outras normas constitucionais. A Constituição dos Estados Unidos da América ${ }^{14}$, de 1787 (art. II, seção 2), por exemplo, estabeleceu que o "Presidente será o chefe supremo do Exército e da marinha dos Estados Unidos [...]". A Constituição do México ${ }^{15}$, de 1917 (art. 89, 6) previu como faculdade e obrigação do Presidente dispor da totalidade da Força Armada Permanente, para a segurança interior e defesa exterior da federação. A Constituição da Nação Argentina ${ }^{16}$, de 1994 (Seção 99, 12), destacou ser o Presidente o comandante-chefe de todas as Forças Armadas da Nação. A Constituição do Equador ${ }^{17}$, de 2008 (art. 147, 16), mencionou ser atribuição e dever do Presidente da República, "exercer a máxima autoridade das Forças Armadas [...]".

De forma diversa, porém no mesmo sentido, preservando as instituições armadas como parte do Poder Executivo, a Lei Fundamental da República Federal da Alemanha ${ }^{18}$, de 1949 (art. 65, a), pós-regime nazista, estipulou que o Ministro Federal da Defesa exerce o poder de ordenança e de comando das Forças Armadas, como membro do Governo Federal, sob o controle do Parlamento Federal ou do Conselho Federal (art. 87 a, 4).

Dentro da organização legística da Constituição brasileira, o Presidente da República, situa-se inserido no título IV (Da organização dos poderes), capítulo II (Do Poder Executivo), sendo considerado o órgão/cargo administrativo que o exerce, com o auxílio dos Ministros de Estado (art. 76). Entre suas atribuições (art. 84, XIII), encontra-se "exercer o comando supremo das Forças Armadas [...]”. Portanto, estão no cerne no texto constitucional

\footnotetext{
${ }^{14}$ ESTADOS UNIDOS DA AMÉRICA. Constituição, 1787.

${ }^{15}$ MÉXICO. Constituição do México, 1917.

${ }^{16}$ ARGENTINA. Constituição da Nação Argentina, 1994.

${ }^{17}$ EQUADOR. Constituição da República do Equador, 2008.

18 ALEMANHA. Lei Fundamental da República Federal da Alemanha, 1949.
} 
que as Forças Armadas são formadas por instituições e são membros do Poder Executivo Federal.

Porém, diferentemente do que o atual Presidente aparentemente desejou expor, essa hierarquia está direcionada entre instituições, entre chefe de Estado e as Forças Armadas. Não se trata de personalizar a figura de uma pessoa, por suas vontades íntimas. De acordo com o artigo 142 da Constituição, as Forças Armadas "são instituições 'nacionais' permanentes e regulares”. Não se tratam de instituições que são comandadas pelo chefe de Governo. Serve aos interesses maiores na nação, dentro de suas atribuições materiais. Disso, deriva dizer que há vinculação ou discricionariedade na determinação ou na autorização pelo Presidente do emprego das Forças Armadas. Há limites em seu exercício, conforme a prescrição constitucional e legal, e sob o controle de outras instituições, como Legislativo, Judiciário e Ministério Público. O emprego das Forças Armadas não é compatível com eventuais arbitrariedades, no sentido de seu emprego distorcido ou contrário às normas constitucionais.

Em meio à hierarquia normativa, a Lei Complementar n. 97/1999, autorizada pela Constituição brasileira (art. 142, parágrafo $1^{\circ}$ ), criou o cargo de Ministro da Defesa, que passa a assessorar o Presidente da República no emprego de meios militares, na função de Presidente do Conselho Militar de Defesa (art. $2^{\circ}$ e art. $3^{\circ}$ ), como órgão de direção superior das Forças Armadas (art. $9^{\circ}$ ). Os chefes das Forças, antes com o patamar de Ministros de Estado, a partir de 1999 (art. 20), obtiveram a designação de Comandantes ${ }^{19}$, o que evidencia a intenção de redução da intervenção das Forças Armadas na seara política.

Dessa forma, há patente compreensão nas normas constitucionais dos países ocidentais de se aliar as instituições militares sob o controle das instituições democráticas civis. A perspectiva de estabelecer graus de força entre poder civil e poder militar estaria superada, segundo alguns autores ${ }^{20}$, frente ao rigor normativo prevalecente.

De outro lado, porém, diante do aspecto histórico recente, que abrange pouco mais de um século, tal relação deve continuar sendo observada de forma aproximada. No Brasil, merece destaque três quebras do regime constitucional vigente, com a atuação ou o apoio essencial das Forças Armadas. A primeira situação gerou o fim da monarquia e o início do período republicano. A segunda, a partir da revolução de 1930, ocasionou a transição entre

\footnotetext{
${ }^{19}$ MAIA NETO, Jacintho. O processo de transformação do exército brasileiro: um estudo sobre os reflexos da era do conhecimento. Coleção Meira Mattos: revista das ciências militares, n. 24, 2011.

${ }^{20}$ MAIA NETO, Jacintho. A gestão estratégica da defesa: novos tempos, novos desafios. Hemisferio Revista del Colegio Interamericano de Defensa. n. 6, 2020, p. 102-122.
} 
o que se denominou de República Velha para a Nova, iniciando um período de ditadura gerido por um governo civil; e a terceira situou-se no período de ditadura militar, período em que os militares assumiram o poder político por mais de duas décadas.

Na relação de poder, de legalidade e legitimidade, entre interesses de grupos de militares e com estreita ligação com políticos civis, restou a prevalência da "hegemonia cultural bélica", com a defesa do "uso da força para alcançar objetivos políticos" e superar a autoridade civil e a ordem normativa vigente ${ }^{21}$. Segundo o autor referido, a Proclamação da República foi um ato ilegal e ilegítimo, já que além de contrariar a ordem normativa constitucional vigente, não havia “a vontade geral da sociedade". De acordo com Prudente ${ }^{22}$, a "Constituição de 1891 teve uma vigência meramente formal. E essa própria Constituição fora redigida de tal forma à facilitar o exercício do poder político pelos coronéis". Os dois primeiros Presidentes eleitos, de forma indireta, foram militares, Marechal Manuel Deodoro da Fonseca e Marechal Floriano Vieira Peixoto, este, após a renúncia daquele.

Em contrapartida, embora ilegal, compreendeu o conflito armado de 1930, marco derradeiro da fase da República Velha, como um ato legítimo, diante do suporte do apoio popular $^{23}$. O discurso da legitimidade estaria fulcrado na suposta "vontade geral da sociedade" e na retórica do progresso ${ }^{24}$, de modo a influenciar a invasão na competência constitucional, típica ou atípica de outro ente. Cabe ressaltar que o uso do termo "progresso" deve ser analisado criticamente. Atos extremos como o Holocausto entre outras formas de genocídio e formas de escravidão ou servidão forçada, propiciados por países imperialistas, demonstram um caminho diverso do progresso, compreendido como "fracasso da civilização" ${ }^{25}$.

Os argumentos que albergam a relação interessada e espúria entre políticos, membros dos Poderes Executivo e Legislativo, entes majoritários, de um lado, e militares, membros das Forças Armadas, de outro, nos assuntos decisivos da República; e o discurso da legitimidade, fundado no hipotético "interesse geral da sociedade" e no "progresso", evidenciam um estado de perigo ao atual sistema constitucional democrático brasileiro, pois não considera os direitos das minorias, mesmo depois do atual estágio de pesquisa pós-

\footnotetext{
${ }^{21}$ FRANCO, André Luiz dos Santos. A sinergia entre a legalidade constitucional e a legitimidade bélica das forças armadas na República Brasileira. Coleção Meira Mattos: revista das ciências militares, n. 24, 2011.

${ }^{22}$ PRUDENTE, Wilson. A verdadeira história do direito constitucional no Brasil. V. 1, Niterói: Impetus, 2009, p. 102.

${ }^{23}$ FRANCO. A sinergia entre a legalidade constitucional e a legitimidade bélica das forças armadas na República Brasileira, cit.

${ }^{24}$ Idem.

${ }^{25}$ BAUMAN, Zygmunt. Modernidade e holocausto. Rio de Janeiro: Jorge Zahar Editor, 2012, p. 30-45.
} 
colonial e decolonial. Revela um descompasso ao próprio Estado democrático de direito e à preservação dos direitos e garantias fundamentais da pessoa humana.

A conjunção da retórica "vontade da maioria" ao ditar: "Nós queremos fazer cumprir o artigo 142 da Constituição. Todo mundo quer fazer cumprir o artigo 142 da Constituição [...]" ao termo normativo "sob a autoridade suprema do Presidente da República", e dentro da interpretação ${ }^{26}$ que defende que os ditames constitucionais não seriam suficientes para garantir a isonomia entre legalidade e legitimidade, a partir de "representações imaginárias coletivas da sociedade brasileira", poderia fazer retornar um estado anterior da segunda grande guerra. As Constituições promulgadas posteriormente e os alinhamentos jurisprudenciais das Cortes Constitucionais ${ }^{27}$ compreenderam a necessidade de se possuir instrumentos que pudessem ser contramajoritários, limitantes da democracia majoritária, referenciando a reação aos horrores do holocausto ${ }^{28}$.

Por isso, tão importante aliar o poder do cargo de Presidente da República, como órgão impessoal, ao emprego das Forças Armadas apenas em suas atribuições constitucionais e legais, e observando-se obrigatoriamente a metodologia procedimental legal, principalmente as constantes nas hipóteses de exceções políticas.

Dessa primeira perspectiva, atinente à natureza hierárquica, pode-se aduzir que as Forças Armadas pertencem ao Poder Executivo Federal, sendo o Presidente da República a autoridade superior. São formadas por instituições nacionais e permanentes. Suas três forças, Marinha, Exército e Aeronáutica estão submetidas ao Ministro da Defesa. Portanto, não se trata de instituições independentes. Não se trata de um ente com função de poder ou detentor de poder político.

\subsection{Perspectiva do preceito de natureza funcional}

A segunda perspectiva de prisma funcionalista visa analisar as atribuições das Forças Armadas. Nesse ponto, três finalidades constitucionais foram determinadas: defesa da Pátria, garantia dos poderes constitucionais e garantia da lei e da ordem.

A primeira está ligada à defesa do patrimônio da nação, seu território, povo e símbolos e encontra-se estritamente relacionada aos atos de guerra e pode se subsumir na

\footnotetext{
${ }^{26}$ FRANCO. A sinergia entre a legalidade constitucional e a legitimidade bélica das forças armadas na República Brasileira, cit.

27 ARGUELES, Diego Werneck. Ellwanger e as transformações do Supremo Tribunal Federal: um novo começo? Revista Direito e Praxis, Rio de Janeiro, 2021.

${ }^{28}$ SWEET, Alec Stone. Constitutional Courts. In M. Rosenfeld e Andras Sajó (orgs.). Oxford handbook of comparative constitutional law. Oxford University press, 2012.
} 
hipótese de decretação de estado de sítio por motivo de agressão externa, depois da aprovação do Congresso Nacional e por meio de um procedimento preestabelecido.

Fatos relacionados à "baixa incidência de guerras", "fatores histórico-militares", contexto da posição geopolítica e "desafios enfrentados por países em desenvolvimento", no entanto, seriam justificativas para a cultura estratégica voltada ao ambiente interno do País ${ }^{29}$. Os limites das fronteiras estão resolvidos, há superação de forças comparadas às dos países vizinhos e existe um bom relacionamento com a potência hegemônica regional norteamericana $^{30}$.

A segunda finalidade visa preservar exatamente o estado democrático de direito, suas instituições e poderes constituídos, Poder Legislativo, Poder Executivo e Poder Judiciário. De acordo com a Lei Complementar n. 97/1999 (art. 15, parágrafo $1^{\circ}$ ), cabe ao Presidente da República autorizar o emprego das Forças Armadas, de ofício ou atendendo ao pedido manifestado por quaisquer dos demais entes de poder, por intermédio do Presidente do Supremo Tribunal Federal, no caso de pedidos advindos do Poder Judiciário, e dos Presidentes do Senado ou Câmara dos Deputados, no caso do Poder Legislativo. A terceira permite manter a lei e a ordem, a pedido de qualquer dos poderes da República.

Essas duas últimas possibilidades de atuação das Forças Armadas existem para garantir o "livre exercício de qualquer dos Poderes nas unidades da Federação", conforme previsão no art. 34, IV, da CF, quando trata da decretação de intervenção federal no EstadoMembro, e do estado de defesa "para preservar ou prontamente reestabelecer a ordem pública ou a paz social, ameaçadas, por grave e iminente instabilidade institucional", podendo evoluir para o estado de sítio. Na forma da norma legal (art. 15, parágrafos $2^{\circ}$ e $3^{\circ}$, da LC 97/1999), a atuação das forças na garantia da lei e da ordem somente poderia ocorrer depois de esgotados os instrumentos das forças policiais e de segurança pública. Para tanto, o chefe do Poder Executivo Federal ou Estadual deve reconhecer a indisponibilidade, a inexistência ou a insuficiência por ato formal. Ou seja, caberia o reconhecimento e o pedido do ente de Poder, federal ou estadual, para ocorrer o emprego das forças militares em sua circunscrição nas atividades excepcionais.

\footnotetext{
29 SANTA BÁRBARA, Marcelo de Jesus; MEDEIROS FILHO, Oscar. O papel trinitário do Exército Brasileiro: bases de uma força "multitarefas". Coleção Meira Mattos: revista das ciências militares, v. 15, n. 53, 2021, p. 147-165.

${ }^{30}$ PROENÇA JÚNIOR, Domício. Forças Armadas para quê? Para Isso? Contexto Internacional, v. 33, n. 2, jul. dez, 2011, p. 334.
} 
Outro detalhe importante. O emprego das Forças Armadas para referido fim, de garantia da lei e da ordem, é destinado à garantia da ordem pública e da incolumidade das pessoas e do patrimônio, relacionadas no art. 144 da Constituição Federal (art. 15, parágrafo $2^{\circ}$, da LC 97/1999). A remessa ao texto que trata da segurança pública tem a função exatamente de relacionar os eventuais deveres que as Forças Armadas teriam em momentos de instabilidade extrema, a ponto de as forças policiais e de segurança serem insuficientes a situação casuística. De modo geral, as funções de segurança pública relacionam atribuições de prevenção a atos ilícitos, administrativos ou criminais e repressão imediata, excluindo-se as atividades de repressão mediata, na apuração das infrações penais comuns (art. 16-A, da LC 97/1999). Além disso, abrange as funções de polícia marítima, aeroportuária, rodoviária e de fronteiras, e a execução de atividades de defesa civil.

Além das três atribuições constitucionais, outras de cunho infraconstitucional foram inseridas, como "atribuições subsidiárias": cooperação com o desenvolvimento nacional; realização de defesa civil; participação em campanhas institucionais de utilidade pública ou de interesse social; atuação em ações preventivas e repressivas na faixa de fronteira terrestre, no mar e nas águas interiores, atuando contra delitos transfronteiriços e ambientais, detendo para tanto poder de polícia; atuação na segurança de dignitários em missões oficiais. As atribuições subsidiárias respectivas de cada Força encontram-se especificadas nos artigos 17, 17-A e 18, da LC 97/1999.

A história do Brasil demonstra a cultura de emprego das Forças Armadas em ações internas, a fim de resolver e por fim aos movimentos dissidentes, revoluções ou revoltas, em desfavor da federação; atuar em atividades de infraestrutura, como a construção e reforma de rodovias, linhas férreas, denominadas atribuições subsidiárias ${ }^{31}$, associadas a políticas públicas e desenvolvimento, também denominadas de "questões cívico-sociais"32; e resolver questões de segurança pública, como a dissidência de greves de policiais e de caminhoneiros, e combate ao narcotráfico nas fronteiras ${ }^{33}$. Estudo confirma que o padrão de emprego das Forças Armadas no Brasil na ordem interna é uma constante, com a prevalência de sua variável histórica, sendo as variáveis regionais, influenciadas pelos Estados Unidos, para o combate ao narcotráfico; e as variáveis internacionais, pós-guerra fria, fatores adjacentes.

\footnotetext{
${ }^{31}$ FRANCO. A sinergia entre a legalidade constitucional e a legitimidade bélica das forças armadas na República Brasileira, cit.

32 SANTA BÁRBARA; MEDEIROS FILHO. O papel trinitário do Exército Brasileiro: bases de uma força "multitarefas", cit.

${ }^{33}$ ALSINA JÚNIOR. João Paulo Soares. Ensaios de grande estratégia brasileira. Rio de Janeiro: FGV Editora, 2018.
} 
Segundo estudo empírico ${ }^{34}$, o emprego militar ocorreu entre 2007 a 2014, em 61 vezes em missões de paz; 68 na defesa de recursos estratégicos e do território; 187 em ações de segurança pública; 21 em trabalhos de obras públicas; 17 na saúde pública; 18 em atividades de assistência a acidentes; e 16 vezes na defesa regional. Quase a metade das situações (47\%) envolvia seu emprego em atividades de segurança pública e apenas (17\%) em ações voltadas a defesa externa.

A doutrina entende que a atuação interna das Forças Armadas por todo o período histórico brasileiro, no contexto de ser um país em desenvolvimento e diante de suas eventuais instabilidades e fragilidades, construiu a identidade da instituição, em um caráter de multitarefas ${ }^{35}$. Uma das críticas revela-se no fato de as Forças Armadas brasileiras desempenharem, mesmo que excepcionalmente, um papel que caberia a forças intermediárias permanentes, como as guardas nacionais, forças nacionais de segurança, polícia federal ou rodoviária federal, assim como funciona em outros vários países ${ }^{36}$.

Ao mesmo tempo, considerou-se haver certa crise de identidade das Forças Armadas, em vários Países, a partir da década de 1990, diante do fato de seu emprego interno constante em atividades atinentes à segurança pública ${ }^{37}$. No Brasil, essa crítica seria mais intensa, na medida da diferenciação das ações estratégicas relativas às políticas de defesa e às políticas de segurança pública ${ }^{38}$. Para essa corrente, o processo de redemocratização no Brasil manteve legados antidemocráticos, como a manutenção da atuação das Forças Armadas para a garantia da lei e da ordem ${ }^{39}$, prestígio na interferência política, privilégios na carreira dos militares e a defesa da lei da Anistia $^{40}$. A resistência à reavaliação do período de ditadura militar seria um dos motivos das dificuldades de consolidação da democracia brasileira $^{41}$.

\footnotetext{
${ }^{34}$ SUCCI JÚNIOR, David Paulo. A construção do atual padrão de emprego das Forças Armadas no Brasil. Revista de Iniciação Científica em Relações Internacionais, v. 4, n. 7, 2016, p. 87.

${ }^{35}$ SANTA BÁRBARA; MEDEIROS FILHO. O papel trinitário do Exército Brasileiro: bases de uma força "multitarefas", cit., p. 152-155.

${ }^{36}$ Ibidem, p. 158.

${ }^{37}$ MISSIATO, Victor Augusto Ramos. Forças armadas, autonomias e autoritarismo: a atuação das Forças Armadas de Brasil e Chile nas transições rumo à democracia. Revista Sul-Americana de Ciência Política, v. 5 , n. 1, 2019, p. 7.

${ }^{38}$ SANTOS, Maria Helena de Castro. A nova missão das Forças Armadas latino-americanas no pós-Guerra Fria: o caso do Brasil. Revista Brasileira de Ciências Sociais, v. 19, n. 54, 2004, p. 119.

${ }^{39}$ SUCCI JÚNIOR. A construção do atual padrão de emprego das Forças Armadas no Brasil, cit., p. 97.

${ }^{40}$ MISSIATO. Forças armadas, autonomias e autoritarismo: a atuação das Forças Armadas de Brasil e Chile nas transições rumo à democracia, cit., p. 8 e 14.

${ }^{41}$ TELES, Edson. O que resta da ditadura: a exceção brasileira. São Paulo, Boitempo, 2010.
} 
Embora a primeira das atribuições seja a originária, as três funções precípuas das Forças Armadas estão inseridas no mesmo grau de importância. ${ }^{42}$ Saint Pierre ${ }^{43}$ descreve que o emprego das Forças Armadas é justificado quando patente à existência de ameaças externas, atinentes à integridade nacional e à soberania nacional, e internas, relacionadas à ordem proteção da ordem constitucional, por suas instituições, e à paz interior. E com as mudanças dessas ameaças ao longo do tempo, há novos direcionamentos e desafios nas gestões estratégicas das Forças Armadas, mais direcionados ao ambiente interno, especialmente, voltados à garantia da lei e da ordem, o que gera certo paradoxo gerencial, como narrou o autor ${ }^{44}$.

A garantia da lei e da ordem nos contextos históricos, políticos e jurídicos significa a ação das Forças Armadas pelo uso da força, com "respaldo coercitivo", "seja no sentido amplo, nacional e institucional, seja no sentido estrito de um momento e espaço específicos"45. Em nenhuma das atribuições constitucionais ou mesmo legais, nem mesmo implicitamente, as forças militares foram alçadas como instituições moderadoras de outros poderes, mesmo que estejam em eventual desarmonia.

O ponto nevrálgico deste estudo foca principalmente na segunda atribuição constitucional das Forças Armadas, atinente à garantia dos poderes constituídos. Essa seria a base jurídica aparentemente defendida pelo Presidente atual quando invocou retoricamente o art. 142 da Constituição.

Da segunda perspectiva, pautada pela análise circunscrita às atribuições normativas das Forças Armadas, compreende-se, no ponto, a necessidade de se observar alguns pressupostos obrigatórios: 1) a preservação das instituições democráticas, por meio da garantia dos poderes constitucionais, está estritamente ligada à garantia da lei e da ordem; 2) a garantia da lei e da ordem realizada por meio das Forças Armadas encontra respaldo coercitivo pelo uso da força bélica, de defesa e segurança pública; 3) a garantia da lei e da ordem é medida excepcional e temporária que depende de alguns fatores/limites: 3.1) circunscreve-se às atribuições constitucionais das instituições de segurança pública, excluindo-se as atividades de repressão mediata, na apuração das infrações penais comuns (atividades próprias de polícia judiciária); 3.2) submete-se ao pedido do Presidente do ente

\footnotetext{
${ }^{42}$ MAIA NETO. A gestão estratégica da defesa: novos tempos, novos desafios, cit.

${ }^{43}$ SAINT-PIERRE, Héctor. As 'novas ameaças' às democracias latino-americanas: uma abordagem teóricoconceitual. In: Eliézer Rizzo de Oliveira. (Org.). Segurança \& Defesa Nacional. Da competição à cooperação regional. $1^{\mathrm{a}}$ ed. São Paulo: Fundação Memorial, 2007, p. 59-82.

${ }^{44}$ MAIA NETO. A gestão estratégica da defesa: novos tempos, novos desafios, cit.

${ }^{45}$ PROENÇA JÚNIOR. Forças Armadas para quê? Para Isso?, cit., p. 336.
} 
do poder ou do ente federativo respectivo para o emprego militar na referida instituição ou circunscrição; 3.3) subordina-se ao esgotamento dos instrumentos das forças policiais e de segurança pública, regulares, devendo haver o reconhecimento da indisponibilidade, da inexistência ou da insuficiência, por meio de ato formal, subscrito pelo chefe do Poder Executivo Federal ou Estadual, responsável pela força de segurança pública na referida circunscrição.

Embora haja pesquisa que indica existir certa fragmentação acerca da destinação das Forças Armadas, o que poderia dar azo "a arroubos e oportunismos" ${ }^{46}$, ainda assim, a perspectiva do atual Presidente da República, não encontra qualquer fundamento político ou jurídico. Em análise jurídico-constitucional observa-se uma interpretação rasa ou superficial, no sentido de interpretação frágil, pois, baseia-se apenas e tão somente em um dispositivo da Constituição que trata das atribuições das Forças Armadas, sem uma análise sistemática. Usa da técnica de interpretação literal ou gramatical de forma incorreta, sem conexão com a técnica legística, e estende limites de exceção não descritos na norma jurídica para fomentar e aumentar seu conteúdo.

Observe-se que a norma constitucional seguiu uma técnica de redação. Estipulou o núcleo essencial ao estabelecer a forma de Estado Federado, a forma de governo republicano e o regime de governo democrático. Regulou um sistema de cláusulas pétreas, núcleo duro, imutável, que impede qualquer discussão tendente a abolir a forma federativa de Estado; o voto direto, secreto, universal e periódico (núcleo essencial do regime político adotado); a separação dos poderes, que se determinaram independentes e harmônicos (sistema de automoderação); e os direitos e garantias individuais. E nas exceções, estabeleceu as hipóteses em rol taxativo, dispondo das regras procedimentais preestabelecidas.

O fundamento que defende que as Forças Armadas são instituições que agem com Poder Moderador ocorreria quando um ente de Poder sentir-se-ia violado em suas competências constitucionais por outro. Por este ângulo, os militares poderiam ser chamados por aquele Poder, a fim de "pontualmente repor a ordem" ${ }^{47}$. O exemplo trazido pelo autor demonstra um hipotético conflito entre a atuação do Supremo Tribunal Federal que exorbitasse de suas competências e ao julgar uma ação declaratória de inconstitucionalidade por omissão, elaborasse uma lei, em desfavor do Congresso Nacional, que nada poderia fazer. Daí, as Forças Armadas que não possuem poder político e nem poder jurisdicional iria

\footnotetext{
${ }^{46}$ PROENÇA JÚNIOR. Forças Armadas para quê? Para Isso?, cit., p. 339.

${ }^{47}$ MARTINS. Cabe às Forças Armadas moderar os conflitos entre os Poderes, cit.
} 
resolver o conflito, por meio da força coercitiva, talvez invadindo o Supremo Tribunal Federal, apreendendo o documento para a destruição.

Pode-se observar que, diferentemente da ilação sem fundamento jurídico razoável $^{48}$, em face da ausência de interpretação sistemática e com base no núcleo essencial da Constituição, não há nenhuma regra que excepcione a independência entre os poderes, cada qual atuando frente às suas competências típicas e atípicas, conforme disposições constitucionais, com independência e harmonia (art. $2^{\circ}$ da Constituição de 1988), e que discorra de procedimento em que as Forças Armadas seriam mediadoras de eventuais “conflitos” entre poderes da República.

Dentro da racionalidade lógica constitucional, se houvesse um quarto poder, com a função de moderar ou decidir por último, depois até que o guardião da Constituição, ele estaria estampado logo nos primeiros capítulos ao lado dos três Poderes da República. No exemplo de conflito aparente apresentado pelo festejado professor e advogado, caberia recurso à própria Corte Suprema ou a elaboração de norma pelo Congresso que pudesse resolver referida omissão ou revogar eventual lei ou julgado com força de lei, de cunho abstrato, elaborada pelo Poder Judiciário.

\subsection{Perspectiva do preceito limitante}

Virando o escopo na busca de decifrar as atribuições e os limites de emprego institucional militar, na ótica das Forças Armadas, na hipótese da determinação do Presidente da República, algumas ponderações são essenciais.

Lições da história da humanidade demonstram o emprego dos atributos das forças militares, por ordem superior, com o uso da coerção como elemento de violência, e violação de direitos fundamentais da pessoa. Dois fenômenos devem ser destacados: a "banalização do mal" e a "produção social da indiferença moral", dentro do contexto deste estudo e da análise do comportamento de Eichmann, durante seu julgamento, pós-segunda grande guerra. Segundo Hanna Arendt, houve uma surpresa quanto ao homem julgado em Jerusalém, então encarregado dos estágios preparatórios do genocídio e da "evacuação forçada aos campos de extermínio" e também de muitos outros membros da SS. Segunda ela, eles não eram loucos, insanos, portadores de ódio, fanáticos, "monstros”, não eram estúpidos e não tinham motivos plausíveis para agir daquela forma. Havia ausência de

\footnotetext{
${ }^{48}$ MARTINS. Cabe às Forças Armadas moderar os conflitos entre os Poderes, cit.
} 
pensamento. Eichmann mostrou-se uma pessoa "incapaz de pensar, de refletir sobre seus atos, suas consequências e seu significado", sem arrependimentos, já que apenas havia cumprido ordens, portanto, tinha a virtude da obediência, e não havia de fato matado pessoas. Foram nos contextos desses fatos que Hanna Arendt melhor compreendeu a expressão "banalização do mal”, e que ela não estaria totalmente em contraste com a noção de "mal radical", como antes deduzia. E daí veio a compreensão de que a prática do mal independe de motivos ou de qualquer estímulo e que poderia haver coincidência entre a "incapacidade de pensar" e o fracasso da "consciência moral" 49 .

Bauman explica o segundo fenômeno, retratado como "produção social da indiferença moral". A violência autorizada pelas normas e pela organização, que pode ser o Estado, um reino, um feudo, gera a ação legitimada, por meio do princípio da "disciplina da organização", no sentido de fazer "obedecer ordens superiores acima de quaisquer outros estímulos à ação". Bauman enfatiza que tal condição foi capaz de obliterar a própria identidade pessoal, como "[...] extremo do sacrifício", reconhecida como virtude moral de honra do funcionário público. Qualquer eventual mal-estar acaba sendo compensado pela exclusiva responsabilidade do chefe e da organização ${ }^{50}$. Arendt, no mesmo sentido, a partir da análise do caso Eichmann, verificou que o acusado se eximiu da culpa e do remorso, diante do fato de ter cumprido a ordem superior, sendo que se foi a organização que determinou é ela que deve assumir a responsabilidade ${ }^{51}$.

Pode-se conceber que o fenômeno da "produção social da indiferença moral" detectado no Holocausto, também é observado, da mesma forma, nos movimentos de colonização mundial e brasileiro, bem como em algumas situações, que retratam a colonialidade ou supremacismo contemporâneo. Permanece especialmente nas relações internas, diante do garantidor e legitimador estatal, como as relações de violência. $\mathrm{O}$ problema ocorre porque aparentemente o jogo ocorre dentro das regras, o mal é suprido por regras burocráticas e pela "aplicação de padrões éticos diferenciados"

Do que se pode extrair do sistema jurídico nacional e das considerações históricas e políticas, os deveres dos militares, como cidadãos brasileiros, e das Forças Armadas, como instituição nacional, estão circunscritos aos seguintes parâmetros mínimos: 1) estar

\footnotetext{
${ }^{49}$ RIBAS, Christina Miranda. Justiça em tempos sombrios: a justiça no pensamento de Hannah Arendt. Ponta Grossa: Toda Palavra, 2019.

${ }^{50}$ BAUMAN. Modernidade e holocausto, cit.

${ }^{51}$ RIBAS. Justiça em tempos sombrios, cit.

52 ROSAS, Fernando. Salazar e os fascismos: ensaio breve de história comparada. Lisboa: Tinta da China, 2019, p.78.
} 
amparado pelas normas constitucionais e legais e deve encontrar ressonância com os precedentes jurisprudenciais; 2) seguir o rigor formal dos procedimentos legais, e obedecer aos preceitos da hierarquia e da disciplina; 3 ) observar os direitos e as garantias fundamentais da pessoa; 4) respeitar a independência dos três Poderes da República e garantir o seu exercício; 5) não agir com função moderadora na decisão de questões políticas e não intervir nas eventuais desarmonias entre as instituições de Poder.

Cabe destacar que o artigo 22 do Código Penal brasileiro dispõe que se "o fato é cometido [...] em estrita obediência a ordem, não manifestamente ilegal, de superior hierárquico, só é punível o autor da coação ou da ordem.” Isso significa que nem toda a ordem de um Presidente da República deve ser cumprida pela força militar. Apenas aquela que esteja dentro dos parâmetros constitucionais e legais, e prudentemente, dos padrões técnicos, deve ser observada pela instituição militar e pelo militar.

3.4 O Poder Moderador e o sistema de divisão de poderes adotado

O Poder Moderador, na lógica descrita por Benjamin Constant ${ }^{53}$, e vigorante no ordenamento jurídico brasileiro, a partir da Constituição de 1824, não está constitucionalizado no Brasil atual ${ }^{54}$. Historicamente, foi criado na França para estabilizar o Estado de Direito no período pós-revolucionário. Aliás, sua constitucionalização no Brasil esteve albergada nesse único momento histórico. Seu objetivo era o de realizar a moderação, a harmonia e o equilíbrio entre os demais poderes ${ }^{55}$. Era delegado ao Imperador, denominado "Chefe Supremo da Nação", de forma "inviolável", "sagrada", e sem sujeições a responsabilidades e limitações (artigos 98 e 99) ${ }^{56}$.

As atribuições exercidas pelo Imperador, no exercício do Poder Moderador, para garantir a "manutenção da independência, equilíbrio e harmonia dos mais Poderes Políticos" (artigos 98 e 101) eram $^{57}:$ 1) nomear Senadores, na forma do Art. 43, limitando as listas de nomes; 2) convocar a Assembleia Geral extraordinariamente nos intervalos das sessões; 3)

\footnotetext{
${ }^{53}$ CONSTANT, Benjamin. Cours de Politique Constitutionelle, avec introduction e notes. $2^{\mathrm{a}}$. ed. Traduit par Edouard Laboulaye. Paris: Guillamin, 1872.

${ }^{54}$ BRASIL. Presidência da República. Casa Civil. Subchefia para Assuntos Jurídicos. Constituição da República Federativa do Brasil, 1988, cit.

${ }^{55}$ LYNCH, Christian Edward Cyril. Estudos brasileiros: o pensamento político como chave de interpretação do Brasil. Entrevistadores: REGINATTO, Victoria Nicolielo; CARVALHO, João Pedro Braga de; SANTANA, Henrique Ferreira. Revista de Ciências do Estado. Belo Horizonte: v. 6, n. 1, 2021.

${ }^{56}$ BRASIL. Presidência da República. Casa Civil. Subchefia para Assuntos Jurídicos. Constituição Política do Império do Brazil, 1824.

${ }^{57}$ Idem.
} 
sancionar os Decretos, e Resoluções da Assembleia Geral, para que tenham força de Lei, na forma do art. 62; 4) aprovar e suspender interinamente as Resoluções dos Conselhos Provinciais, na forma dos artigos 86, e 87; 5) prorrogar ou adiar a Assembleia Geral, e dissolver a Câmara dos Deputados, nos casos, em que o exigir a salvação do Estado, e de convocar imediatamente outra, que a substitua; 6) nomear e demitir livremente os Ministros de Estado; 7) suspender os magistrados nos casos do Art. 154, que se refere a questões relacionadas a "queixas"; 8) perdoar e moderar as penas impostas e os réus condenados por sentença; 9) conceder anistia em caso urgente, e que assim aconselhem a humanidade, e bem do Estado.

No Brasil, funcionou no período do segundo reinado, um momento de transição que "funcionou como uma espécie de cápsula institucional que permitiu ao chefe de Estado obrar conforme a razão de Estado dentro das práticas constitucionais", o que permitiu a Dom Pedro II gozar de legitimidade em três sentidos: "racional-legal, decorrente da Constituição de 1824", "carismática, decorrente da "unânime declaração dos povos"”, e "tradicional", em virtude da hereditariedade ${ }^{58}$.

Muitas diferenças podem ser observadas entre o papel moderador exercido pelo Imperador e o suposto e implícito papel moderador das Forças Armadas, na comparação entre os textos magnos.

Na primeira perspectiva de análise, referente ao caráter hierárquico, verifica-se que o Imperador era a mais alta autoridade do sistema imperial monárquico, sendo-lhe garantida explicitamente na Constituição a condição de chefe supremo da nação. As Forças Armadas são subordinadas às ordens do Presidente da República, por meio de um sistema normativo pré-estabelecido. Portanto, defender que as Forças Armadas teriam Poder Moderador ou função de moderar, ainda que excepcionalmente, seria dizer que o Presidente da República deteria esse poder, já que a força militar não detém poder político.

Baseado na segunda perspectiva, de natureza funcional, constata-se que as atribuições são diversas entre os cargos, especialmente no sentido material. O Imperador tem a função de governar o Poder Executivo e moderar os Poderes Políticos. O outro se trata de um órgão de defesa da Nação, pelo uso ou ameaça de uso das armas.

Explorando as atribuições que se entendeu como própria de uma função moderadora pelas Forças Armadas, no sentido de "garantir os poderes constitucionais",

\footnotetext{
${ }^{58}$ LYNCH. Estudos brasileiros: o pensamento político como chave de interpretação do Brasil, cit.
} 
prevista no art. 142 da Constituição de 1988, e a função moderadora de garantir a "manutenção da independência, equilíbrio e harmonia dos mais Poderes Políticos", prevista no art. 98 da Constituição de 1824, há uma aparente leve semelhança nos termos constitucionais. No entanto, sem embargo, as atribuições moderadoras, pelas quais a função seria exercida, conforme o art. 101 da Constituição de 1824, elas não se relacionam com as atribuições das Forças Armadas e nem mesmo do próprio Presidente da República. A Constituição de 1988 , por seu art. $2^{\circ}$, deixou bem lídimo que os critérios da independência e da harmonia são exercidos pelos entes que possuem o poder político, Legislativo, Executivo e Judiciário. Não há outra instituição que pudesse fazer isso.

Martins ${ }^{59}$ fundamenta sua posição no sentido de defesa dos poderes constitucionais na hipótese de violação ou usurpação de competências constitucionais. Fato é que naquele período se um juiz recebesse alguma queixa, de acordo com a vontade subjetiva do Imperador, ele poderia ser suspenso. Da mesma forma, se o Imperador entendesse que alguma Resolução dos Conselhos Provinciais fosse equivocada, diante de elementos subjetivos previstos na norma, sob os termos "se julgar que ellas são dignas" (art. 86) poderia suspendê-la. O mesmo ocorre com a possibilidade de dissolução da Câmara dos Deputados, por seu requisito subjetivo descrito como "nos casos, em que o exigir a salvação do Estado".

O Poder Moderador existia para manter um controle sobre todas as instituições e estava em patamar superior a elas, por meio de critérios meramente subjetivos e pessoalizados, independente de requisitos objetivos preestabelecidos e do devido processo legal, condições necessárias na amplitude atual. Não havia na época, no entanto, democracia, como regime político, e nem Estado democrático, no sentido contemporâneo. A nova situação que se coloca em análise, portanto, não se trataria de uma instituição com Poder Moderador.

Poderia ainda se ponderar sobre uma instituição que teria supostamente uma função moderadora, porém, no sentido de ser o guardião da Constituição, já que as atribuições do Imperador não são as mesmas que o texto paradigmático quer destacar.

De acordo com a terceira perspectiva de análise, alusivo ao fator legal limitante, as diferenças também são gritantes. O Imperador, frente ao sistema constitucional, é descrito pelo texto magno como a maior autoridade da nação e não estava sujeito a qualquer responsabilidade (art. 99). Os membros das Forças Armadas estão circunscritos aos

\footnotetext{
${ }^{59}$ MARTINS. Cabe às Forças Armadas moderar os conflitos entre os Poderes, cit.
} 
princípios da administração pública, entre eles a impessoalidade, respondem por seus atos de acordo com as leis do País. As instituições das Forças Armadas estão passíveis de controle por outras instituições.

Alguns cientistas políticos contemporâneos defendem o retorno do poder moderador, no entanto, de forma constitucionalizada, sugerindo-se o seu exercício por meio de um Conselho de Estado formado por membros natos ou pelo Senado ${ }^{60}$, a fundamento de que fatos históricos demonstram a supremacia de um poder sobre outros. Compara superioridades que considera autoritárias, impostas historicamente ao longo dos anos, mesmo sem estar legalizado democraticamente, porém, por outras formas, como a acumulação de poderes no executivo, durante os períodos constitucionais de $1937^{61}$ e depois a partir dos atos institucionais da ditadura militar ${ }^{62}$; e o excesso de intervenção jurisdicional, pós Constituição de 1988.

Como função moderar os eventuais conflitos entre os poderes, outros, por sua vez, compreendem que a referida função estaria mais centrada em um Tribunal Constitucional, a partir das teorias de Kelsen ${ }^{63}$, o que estaria mais próximo do ordenamento jurídico e tradição brasileira em contraponto aos reflexos do passado.

Relembra Cynara Mariano ${ }^{64}$ o embate clássico entre Carl Schmitt e Hans Kelsen a respeito da titularidade do exercício da jurisdição constitucional. Schmitt ${ }^{65}$ defendia que a função de guardião da constituição deveria ser exclusiva do chefe de Estado (único representante), tendo em vista ter sido eleito diretamente pelo povo, ter a qualidade de neutralidade e de moderador, como para um imperador, alguém acima das paixões políticas e das funções executivas de Estado. Para ele, o fato de ser exercido por "um" revela maior probabilidade do exercício de uma função unificadora e harmoniosa, o que a história mostrou ser inverdade. Kelsen ${ }^{66}$, de outro lado, postulava pela construção de um modelo de jurisdição constitucional, para exercer o controle abstrato de constitucionalidade, formado por um "corpo coletivo", porém, distinto do Judiciário e dos outros poderes, como um Tribunal

\footnotetext{
${ }^{60}$ HORTA, José Luiz Borges. Dialética do poder moderador: ensaio de uma ontoteleologia do Estado do Brasil. Tese (Titularidade em Teoria do Estado). Belo Horizonte: Universidade Federal de Minas Gerais, 2020. ${ }^{61}$ BRASIL. Presidência da República. Casa Civil. Subchefia para Assuntos Jurídicos. Constituição dos Estados Unidos do Brasil, 1937.

62 BRASIL. Presidência da República. Casa Civil. Subchefia para Assuntos Jurídicos. Constituição da República Federativa do Brasil, 1969.

${ }^{63}$ KELSEN, Hans. Quién debe ser el defensor de la Constitución? Madrid, Tecnos, 1995.

${ }^{64}$ MARIANO, Cynara Monteiro. O debate sobre a separação dos poderes no pensamento constitucional brasileiro. Revista Direitos Fundamentais \& Democracia, Curitiba, v. 4, n. 4, jul. dez 2008.

${ }^{65}$ SCHMITT, Carl. La Defensa de la Constitución. Madrid: Labor, 1931.

${ }^{66}$ KELSEN. Quién debe ser el defensor de la Constitución?, cit.
} 
Constitucional, tese influenciadora de várias nações europeias. Contrapõe Schmitt no sentido de que não haveria neutralidade do chefe de Estado, já que ele domina a política. Tornar-seia um superpoder partidário-ideológico ${ }^{67}$.

Segundo Lynch $^{68}$, há elementos constatáveis no excesso de linguagem e na forma de prática de alguns atos, demonstrados nas décadas de 2010 e 2020, no Brasil, sobre disputas que visam restabelecer essa função moderadora, entre o judiciário, por seu órgão de cúpula, o Supremo Tribunal Federal e, de outro lado, alguns militares federais, representados por militares da reserva, vinculados ao atual Presidente da República, representante do executivo. Alguns autores ${ }^{69} 70$ traduzem que uma saída seria a transformação da Corte Suprema brasileira em Tribunal Constitucional ao modelo europeu, com a principal atribuição de guardião da Constituição, sem competências para processar e analisar casos individuais e concretos, mesmo em grau recursal.

De outra ordem, a inserção do poder moderador e mesmo da função moderadora não haveria espaço no atual modelo constitucional sem o rompimento da ordem constitucional vigente. O princípio da separação dos poderes em instituições diversas, e executado por pessoas ou instituições diversas ${ }^{71}$ em legislativo, executivo e judiciário, adotado pela Constituição, faz parte do núcleo imutável da Constituição, como dispõe o art. 60, parágrafo $4^{\circ}$, da Constituição promulgada em 1988.

Trazendo exemplos de várias Repúblicas e Monarquias da era antiga, medieval e moderna, Montesquieu, no livro 11 (Das leis que formam a liberdade), capítulo VI, declara que "quando na mesma pessoa ou no mesmo corpo [...]" são exercidas as três espécies de poder, "[...] não existe liberdade" ou haveria menos liberdade. O governo precisaria para se manter "de meios tão violentos". Conclui que nessas condições, a centralização de poder em uma só pessoa pode "devastar o Estado com suas vontades gerais e [...] pode destruir cada cidadão por suas vontades particulares."72 Traduzindo os ideais iluministas da época, o autor entendia o Judiciário como um poder "de algum modo, nulo" politicamente, já que compreendia o juiz como "a boca que pronuncia as sentenças da lei, seres inanimados que não podem moderar nem sua força, nem seu rigor." Por outro lado, para fins de moderação

\footnotetext{
${ }^{67}$ MARIANO. O debate sobre a separação dos poderes no pensamento constitucional brasileiro, cit.

${ }^{68}$ LYNCH. Estudos brasileiros: o pensamento político como chave de interpretação do Brasil, cit.

${ }^{69}$ Idem.

${ }^{70}$ MARIANO. O debate sobre a separação dos poderes no pensamento constitucional brasileiro, cit.

${ }^{71}$ MONTESQUIEU. Do espírito das leis, cit.

${ }^{72}$ Idem.
} 
entre os poderes legislativo e executivo, trazia exemplos que atualmente podemos denominar de funções atípicas dos entes de poder, como o poder de veto do executivo ${ }^{73}$.

Os ideários do Judiciário, por meio de prolações judiciais, decidirem questões políticas constitucionais, dos demais poderes, como guardião da Constituição, surgiu nos Estados Unidos, conforme os argumentos de Marshall ${ }^{74}$, no caso Marbury versus Madison, ocorrido em 1803, embora haja relatos de que a publicação "O Federalista" controle judicial de constitucionalidade já estava na Constituição, mas isso não resta claro. Os federalistas diziam que o judiciário não se transformava por isso em um superpoder, pois o que fazia era nada mais que analisar duas leis em conflito.

Nas linhas de Montesquieu, por suas razões, Madison ${ }^{76}$ defende que os poderes não podem permanecer nas mãos de uma mesma pessoa ou mesma corporação, pois geraria efeitos de tirania, arbítrio e opressão. Propõe que um poder não exercite completamente as funções dos outros. Poderia, no entanto, por convenção na constituição, admitir a mistura parcial delas. Traz exemplos: o uso do "veto" com limitações das decisões do legislativo pelo "magistrado executor" (executivo); o julgamento do processo de impeachment dos membros do executivo e do judiciário, por meio do senado (legislativo), que atua como um "tribunal"; a nomeação de juízes pelo executivo.

Hamilton $^{77}$ enfatizou que a separação de poderes não poderia ser apenas formalizada, mas sim teria que vir acompanhada de elementos concretos a fim de gerar efeitos como a independência, como a necessidade de cada um ter "uma vontade própria". Além disso, seria importante que uma instituição de poder tenha a "menor influência possível" na outra quando do exercício das funções atípicas, estabelecendo um sistema de construção de governo que possua freios e contrapesos. Marshall ${ }^{78}$ defendeu que se a interpretação era sobre leis em conflito, entre si, ou envolvendo normas estabelecidas pela Constituição, a competência seria do judiciário, diante da natureza de sua existência.

Definido tal controle de forma secular, há discussões teóricas atuais a respeito da legitimidade democrática de o judiciário, poder contramajoritário, invalidar lei elaborada pelo legislativo, poder majoritário. Dworkin ${ }^{79}$ defende o sistema de controle de

\footnotetext{
${ }^{73}$ Idem.

${ }^{74}$ MARSCHALL, John. Decisões constitucionais. Imprensa nacional, 1908.

${ }^{75}$ HAMILTON; MADISON; JAY. O Federalista, cit.

76 Idem.

${ }^{77}$ Idem.

${ }^{78}$ MARSCHALL. Decisões constitucionais, cit.

${ }^{79}$ DWORKIN, Ronald. Direito da liberdade: a leitura moral da Constituição norte-americana. São Paulo: Martins Fontes, 2006.
} 
constitucionalidade norte-americano denominado judicial review baseado em vários argumentos, entre os quais de que, quando se envolve princípios constitucionais, a qualidade do debate público é aprimorada em um Tribunal técnico, e não há evidências de que o sistema de controle de constitucionalidade viole a democracia ou seus princípios, exatamente por ter resolvido várias questões cruciais que envolvem direitos fundamentais e direitos políticos. Waldron $^{80}$, por sua vez, aponta críticas à posição de Dworkin, no sentido de desconstruir seus argumentos e defender que o sistema norte-americano de controle de constitucionalidade teria menor legitimidade, pois as questões democráticas são impostas por uma instituição não democrática. Tushnet ${ }^{81}$ aponta crítica ao judiciário com certo ceticismo quanto à implementação dos direitos humanos positivados pelos mecanismos institucionais, especialmente pelo judiciário no judicial review.

Não é preciso relembrar, mais uma vez, que o Brasil, em menos de 100 anos, foi submetido ao regime de duas ditaduras ou regimes totalitários e ainda passou por contínuos períodos oligárquicos e de limitação democrática, o que vinha a significar menos liberdade e maior uso da força extremada como violência do Estado. E foi a Constituição de 1988, depois de larga discussão técnica e ideológica, sobre críticas e elogios de todos os fronts (movimentos de esquerda e de direita) que propiciou que o Legislativo e o Judiciário passassem a ter mais poderes, antes centralizados no Executivo, com a redução de seus instrumentos de força, como a extinção do Decreto-Lei, então elemento autoritário e de exceção, e de sua ilimitada competência ${ }^{82}$.

Explica Cittadino ${ }^{83}$ que o debate sobre o papel e competência do Supremo Tribunal Federal iniciou-se no âmbito da Comissão de Organização dos Poderes e Sistema de Governo, na Subcomissão do Poder Judiciário e do Ministério Público. De início foi defendido que a Corte Suprema do país deveria dedicar-se apenas às questões constitucionais, como Corte Constitucional. No entanto, embora apenas parte de suas competências tenha sido excluída, passando ao Superior Tribunal de Justiça, foi-lhe atribuída a função de guardião da Constituição. Diante disso, com a nova função, assumiu o Supremo

\footnotetext{
${ }^{80}$ WALDRON, Jeremy. O judicial review e as condições da democracia. In: BIGONHA, Antônio Carlos Alpino e MOREIRA, Luiz (org.). Limites do controle de constitucionalidade. Coleção ANPR de direito e democracia. Rio de Janeiro: Lumen Juris, 2009, p. 243-270.

${ }^{81}$ TUSHNET, Mark. Ceticismo sobre o Judicial Review: uma perspectiva dos Estados Unidos. In: BIGONHA, Antônio Carlos Alpino e MOREIRA, Luiz (org.). Limites do Controle de Constitucionalidade. Coleção ANPR de direito e democracia. Rio de Janeiro: Lumen Juris, 2009.

82 BONAVIDES, Paulo. História constitucional do Brasil. 3. ed., Rio de Janeiro: Paz e Terra, 1991.

83 CITTADINO, Gisele. Pluralismo, direito e justiça distributiva: elementos de filosofia constitucional contemporânea. 5. ed. Andradina: Meraki, 2020.
} 
Tribunal Federal caráter político ou de repercussão política, no sentido de declarar o sentido e alcance de normas jurídicas constitucionais. Convém destacar que as normas constitucionais possuem caráter político, a servir ora como fator de legitimação, vez que no passado a sociedade atribuiu ao Estado o poder político, ora a servir como fator de limitação, a considerar que a atuação do Estado está limitada pelos direitos fundamentais. Daí a conclusão de que a interpretação da Constituição Federal também possui caráter político e de que os órgãos responsáveis por interpretá-la também atuam de modo político.

Dessa forma, como poderia as Forças Armadas substituir o Poder Judiciário na interpretação Constitucional? Não poderia. Outras formas de institucionalização de poder como o unipartidarismo, o militarismo e o fundamentalismo são meios ultrapassados, ao oposto de constitucionalismo democrático ${ }^{84}$. E no caso de exorbitância da decisão judicial pela Corte Suprema caberia recurso à própria Corte, e não a nenhum oficial das forças armadas ou comissão de oficiais, por ausência de qualquer legitimidade e competência constitucional. Seria no mínimo parcial um grupo de oficiais das Forças Armadas decidirem eventuais "conflitos" entre Poderes da República, inclusive, quando envolvesse o Poder Executivo, com o Presidente da República sendo sua autoridade suprema. Por sua natureza de ação, as forças armadas fazem parte do executivo ${ }^{85}$. Não se verifica a possibilidade do predomínio de poder executivo sobre o judiciário na matéria de dar a última opinião constitucional em um caso em concreto e muito menos em análise abstrata de constitucionalidade, que não seja um excesso de poder próximo da tirania, próprios de regimes ditatoriais. Como esclarece Waldron ${ }^{86}$, há outros sistemas de controle de constitucionalidade nos países democráticos executados pelo legislativo, mas não pelo executivo. O modelo defendido por $\mathrm{Schmitt}^{87}$ determinou, a partir de experiências recentes do século XX, o funcionamento do Estado alemão sob o manto da "ditadura constitucional", como "fase de transição que leva fatalmente à instauração de um regime totalitário" 88 .

Em decisão liminar, o Ministro Fux, do Supremo Tribunal Federal, ao examinar a questão, argumentou e deliberou no seguinte sentido: 1) na missão das Forças Armadas não se inclui o poder moderador entre os poderes da República; 2) a chefia das Forças Armadas é poder limitado, excluindo-se qualquer interpretação que permita sua utilização para

\footnotetext{
${ }^{84}$ BARROSO, Luís Roberto. Temas de Direito Constitucional. Rio de Janeiro: Renovar, 2001.

${ }^{85}$ MONTESQUIEU. Do espírito das leis, cit.

${ }^{86}$ WALDRON. O judicial review e as condições da democracia, cit.

${ }^{87}$ SCHMITT. La Defensa de la Constitución, cit.

${ }^{88}$ AGAMBEN, Giorgio. Estado de exceção. 2. ed. São Paulo: Boitempo, 2004.
} 
indevidas intromissões no independente funcionamento dos outros Poderes, relacionando-se a autoridade sobre as Forças Armadas às competências materiais atribuídas pela Constituição ao Presidente da República; 3) A prerrogativa do Presidente da República de autorizar o emprego das Forças Armadas, por iniciativa própria ou em atendimento a pedido manifestado por quaisquer dos outros poderes constitucionais - por intermédio dos Presidentes do Supremo Tribunal Federal, do Senado Federal ou da Câmara dos Deputados -, não pode ser exercida contra os próprios Poderes entre si; 4) O emprego das Forças Armadas para a "garantia da lei e da ordem", embora não se limite às hipóteses de intervenção federal, de estados de defesa e de estado sítio, presta-se ao excepcional enfrentamento de grave e concreta violação à segurança pública interna, em caráter subsidiário, após o esgotamento dos mecanismos ordinários e preferenciais de preservação da ordem pública e da incolumidade das pessoas e do patrimônio, mediante a atuação colaborativa das instituições estatais e sujeita ao controle permanente dos demais poderes, na forma da Constituição e da lei ${ }^{89}$.

Com os argumentos acima, não há uma instituição própria na Constituição brasileira promulgada em 1988, que tenha exclusivo poder ou função moderadora. O sistema de separação dos poderes, composto por três instituições e cada qual, com suas funções típicas e atípicas, atuam de forma independente e harmônica. A função moderadora é realizada conjuntamente, por meio das funções típicas e atípicas. Não cabe às Forças Armadas o poder de moderar as instituições da República. Não há quaisquer elementos nas Constituições de outros Países pesquisadas que possam servir de paradigma.

Portanto, tal conjectura de defender que forças militares, sem poder político, subordinadas ao Poder Executivo Federal, chefiadas pelo Presidente da República, por ordem dele, poderiam atuar com função moderadora, mesmo em situações excepcionais e pontuais, intervindo em instituições com poder político, com o uso ou ameaça de coerção, e sem haver requisitos mínimos objetivos que poderiam respaldar tal tese, tende a fomentar a narrativa de estilo retórico, de natureza populista e personalista, de cunho binário, que visa atender elementos de confronto entre o bem e o mal, entre "nós" e "eles"90.

3.4 O suposto alarde anticonstitucional e antidemocrático

\footnotetext{
${ }^{89}$ BRASIL. SUPREMO TRIBUNAL FEDERAL. ADI 6457 MC / DF - Distrito Federal. Medida cautelar na ação direta de inconstitucionalidade, Relator(a): Min. Luiz Fux, Julgamento: 12/06/2020.

${ }^{90}$ SCHLEGEL, Rogério. Impactos políticos da educação: da aposta no novo cidadão à eleição de Bolsonaro. Revista Educação Social, v. 42, 2001.
} 
A forma de comunicação e transmissão de argumentos utilizados pelo atual Presidente da República, mas que poderia estar presente em qualquer outro chefe do Poder Executivo Federal brasileiro, defendendo que as Forças Armadas interfiram em decisões políticas e judiciais de outros Poderes, a fim de exercer a função moderadora pressuposta, evidencia um caráter no mínimo suspeito de suas convicções, ainda mais porque ocorreu na esfera pública e no exercício do cargo público.

Segundo Levitsky e Ziblatt ${ }^{91}$, baseado em estudos observacionais em várias democracias que se tornaram autocracias, a destruição de um sistema democrático pode acontecer de forma gradual, por meio de ações que individualmente parecem insignificantes, apresentam-se situadas aparentemente dentro da lei, e muitas vezes com a retórica de elevado valor público, como combater a corrupção, melhorar o sistema de eleições, aperfeiçoar a democracia, combater crise econômica ou mesmo inventar um estado de crise, como supostamente ocorreu quando Hitler justificou a imposição de decretos emergenciais que reduziram as liberdades civis, a partir do evento de um incêndio no parlamento alemão.

De acordo com os autores acima, os cidadãos não percebem os ardis utilizados. Depois age de forma a retirar o poder de ação dos demais poderes, mediante a alteração de autoridades e outros funcionários, de forma a capturá-las à sua causa. Aos juízes incorruptíveis são formados dossiês sob a acusação de condutas ilegais ou então organizando mudanças de composição do tribunal e, nos casos extremos, destruir completamente as cortes e criar uma nova composta com membros leais a vontade autoritária, como ocorreu na Venezuela, em 1999. As várias manifestações contra a instituição, Supremo Tribunal Federal, constantes nas redes sociais depois de ataques verbais do Presidente da República na referida reunião, que se prolonga, demonstram certa familiaridade com o que ocorreu na Venezuela. Alertam referidos autores que protestos públicos são importantes à democracia, mas desde que sejam em defesa dos direitos e das instituições e não propondo sua ruptura.

Para se manter no poder, os autocratas visam mudar as "regras do jogo" e buscam reformar a Constituição e o sistema eleitoral e outras instituições, a fim de favorecer suas posições ${ }^{92}$. Ginsburg; Huq ${ }^{93}$ chamam a atenção para quatro comportamentos de governos autocráticos ou supostamente democráticos que se repetem em vários países, como alertando para questões de segurança nacional, a fim de restringir direitos; eliminando oponentes, por

\footnotetext{
${ }^{91}$ LEVITSKY, Steven; ZIBLATT, Daniel. Como as democracias morrem. Rio de Janeiro: Zahar, 2018.

${ }^{92}$ Idem.

${ }^{93}$ GINSBURG, Tom; HUQ, Aziz. How to save a constitutional democracy. Chicago: University of Chicago Press, 2018.
} 
meio de intimidações, demissões; por meio de ataques à sociedade civil e imprensa; e enfraquecimento da autoridade da ciência, reduzindo fundos para pesquisas, por meio da politização de debates científicos, e visando favorecer uma agenda negativa de direitos humanos.

Alguns autores enfatizam que alguns movimentos e uso de argumentos, por meio da retórica populista ${ }^{94}$, relevados ao longo destes últimos anos desenham características assemelhadas ao ur-fascismo ${ }^{95}$ ou novo fascismo, com um traço de ficção política, ou movimento de revolta na ordem ${ }^{96}$, ainda que de forma inicial ou primitiva e sem a estrutura de apoio suficiente, como o culto à tradição, a recusa à modernidade e à ciência, não aceitação de críticas, busca do consenso em detrimento da valorização das diferenças e da pluralidade, discursos de ódio ${ }^{97}$, busca do apoio de classes frustradas, obsessão pela conspiração, existência de um inimigo constante com o uso de sua sombra ${ }^{98}$, estado de guerra permanente.

O fato de maior risco é o potencial ameaçador resultante da banalização dos valores outros, e a divulgação de suas ideologias mascaradas por todos os lados ${ }^{99}$. Para Maria Fariñas ${ }^{100}$, há um “jogo perigoso" que se instalou em várias democracias liberais, por meio de mensagens emotivas e populistas que promovem agitações de massa e antissistema, defendendo supostos valores morais tradicionais, mas que, ao revés, extrai do público-alvo o foco da discussão dos problemas reais. A “polarização" radical também pode ser estratégia para destruir democracias ${ }^{101}$. Não há instrumentos institucionais capazes "de garantir que os poderes de emergência sejam usados para salvar a Constituição"102.

De outro lado, não há elementos na pesquisa que possam deduzir que a intenção do Presidente da República atual seja de dar golpe de Estado, desenvolver outra Constituição, destruir o regime e o Estado democrático e tornar-se um autocrata. Pode ter usado do discurso como fonte de exercício argumentativo e de retórica, garantido pelo direito fundamental à livre manifestação e expressão.

\footnotetext{
${ }^{94}$ ROSAS. Salazar e os fascismos, cit.

${ }^{95}$ ECO, Umberto. O fascismo eterno. in Cinco Escritos Morais. Rio de Janeiro: Record, 1998.

${ }^{96}$ BERNARDO, João. Labirintos do fascismo. Na encruzilhada da ordem e da revolta. 3. ed., 2018.

97 ARAGONESES, Alfons. La construcción del enemigo como base del (neo)fascismo. In: GUAMÁN, Adoración et al (Dirs). Neofascismo. La bestia neoliberal. Titivillus, cap. VII, 2020.

${ }^{98}$ BERNARDO. Labirintos do fascismo, cit.

${ }^{99}$ Idem.

${ }^{100}$ FARIÑAS, Maria José. Supremacismo e fascismo. In: GUAMÁN, Adoración et al (Dirs). Neofascismo. La bestia neoliberal. Titivillus, 2020.

${ }^{101}$ LEVITSKY; ZIBLATT. Como as democracias morrem, cit.

102 AGAMBEN. Estado de exceção, cit.
} 


\section{Considerações finais}

Do ponto de vista histórico-político e jurídico não seria possível qualquer interpretação no mínimo racional e razoável da Constituição brasileira que levasse às Forças Armadas a se tornarem um Poder Moderador, superior aos demais poderes, como se transformassem no guardião do "guardião da Constituição". Da mesma forma, não se encontrou guarida para as Forças Armadas desenvolverem atividades com função moderadora na hipótese de dissenso entre os entes políticos republicanos.

As Forças Armadas são instituições nacionais e não detém poder político e nem jurisdicional. Estão subordinadas ao Poder Executivo Federal. As ações previstas no art. 142 do texto são respostas executivas às ordens de quaisquer poderes para que as Forças Armadas atuem em operações de segurança pública ou segurança militar, em casos de insuficiência das forças de segurança pública. Sem desmerecer sua magnitude como instrumento de Estado para a preservação da democracia e de suas instituições, não há quaisquer dispositivos que permita membros das Forças Armadas interpretar leis e decidir para alterar decisões do Judiciário, do Legislativo, ou mediar conflitos entre poderes da república, e nem há competências políticos-constitucionais descritas no referido sentido.

Dentro da ciência política voltada a preservar os direitos fundamentais, não há teorias razoáveis e nem modelos semelhantes em países ocidentais democráticos, que embasem ou gerem legitimidade para a ação das Forças Armadas como moderadora dos poderes da República. Nestes termos, quaisquer teorias que visem eleger instituições militares, subordinadas ao Poder Executivo, em grau superior aos poderes constituídos democraticamente, por suas instituições, mesmo em situações excepcionais, e as desenhem com poder de decidir em última instância, em casos de dissenso, podem ser consideradas autoritárias, deslegitimadas e/ou contra a ordem de direito democrática. O Poder Executivo deve respeito à Constituição do País como todos os demais. Encontra-se ultrapassada a teoria que o determine guardião das normas constitucionais de maneira suprema aos outros poderes.

O que transparece é que alguns sinais, por coincidência ou não, estão aparecendo e eles são muitos semelhantes aos que os teóricos do estado de exceção e teorias de quebra da democracia representaram em outros países, na sociedade mundial democrática e contemporânea. O fato de se defender que instituições oficiais armadas, sem poder político e subordinadas ao Poder Executivo, possam interferir em instituições que possuem poder 
político, dentro de uma suposta atribuição moderadora, traz a lume uma evidência com caráter no mínimo suspeito de suas convicções, embora, em contrapartida, tais argumentações possam traduzir apenas um discurso retórico, garantido como direito de expressão. 


\section{Referências bibliográficas}

AGAMBEN, Giorgio. Estado de exceção. 2. ed. São Paulo: Boitempo, 2004.

ALEMANHA. Grundgesetz für die Bundesrepublik Deutschland, 1949. Disponível em: < https://www.gesetze-im-internet.de/gg/bjnr000010949.html >. Acesso em: 10 ago. 2021.

ALSINA JÚNIOR. João Paulo Soares. Ensaios de grande estratégia brasileira. Rio de Janeiro: FGV Editora, 2018.

ARAGONESES, Alfons. La construcción del enemigo como base del (neo)fascismo. In: GUAMÁN, Adoración et al (Dirs). Neofascismo. La bestia neoliberal. Titivillus, cap. VII, 2020.

ARGENTINA. Constitución Nacional del Argentina, 1994. Disponível em: < https://www.congreso.gob.ar/constitucionNacional.php >. Acesso em: 10 ago. 2021.

ARGUELES, Diego Werneck. Ellwanger e as transformações do Supremo Tribunal Federal: um novo começo? Revista Direito e Praxis, Rio de Janeiro, 2021.

BARROSO, Luís Roberto. Temas de Direito Constitucional. Rio de Janeiro: Renovar, 2001.

BAUMAN, Zygmunt. Modernidade e holocausto. Rio de Janeiro: Jorge Zahar Editor, 2012.

BBC NEWS - BRASIL. O que é o artigo 142 da Constituição, que Bolsonaro citou por intervenção das forças armadas? Disponível em: <http://www.planalto.gov.br/ccivil_03/constituicao/constituicao.htm>. Acesso em: 07 jan. 2021.

BERNARDO, João. Labirintos do fascismo. Na encruzilhada da ordem e da revolta. 3. Ed., 2018.

BONAVIDES, Paulo. História constitucional do Brasil. 3. ed., Rio de Janeiro: Paz e Terra, 1991.

BRASIL. Presidência da República. Casa Civil. Subchefia para Assuntos Jurídicos. Constituição Política do Império do Brazil, 1824. Disponível em: < http://www.planalto.gov.br/ccivil_03/constituicao/constituicao24.htm>. Acesso em: 07 jan. 2021.

Presidência da República. Casa Civil. Subchefia para Assuntos Jurídicos. Constituição da República dos Estados Unidos do Brasil, 1891. Disponível em: < http://www.planalto.gov.br/ccivil_03/constituicao/constituicao91.htm>. Acesso em: 07 jan. 2021.

- Presidência da República. Casa Civil. Subchefia para Assuntos Jurídicos. Constituição da República dos Estados Unidos do Brasil, 1934. Disponível em: < http://www.planalto.gov.br/ccivil_03/constituicao/constituicao34.htm>. Acesso em: 07 jan. 2021.

- Presidência da República. Casa Civil. Subchefia para Assuntos Jurídicos. Constituição dos Estados Unidos do Brasil, 1937. Disponível em: < http://www.planalto.gov.br/ccivil_03/constituicao/constituicao37.htm>. Acesso em: 07 jan. 2021.

. Presidência da República. Casa Civil. Subchefia para Assuntos Jurídicos. Constituição dos Estados Unidos do Brasil, 1946. Disponível em: < http://www.planalto.gov.br/ccivil_03/constituicao/constituicao46.htm>. Acesso em: 07 jan. 2021.

- Presidência da República. Casa Civil. Subchefia para Assuntos Jurídicos. Constituição da República Federativa do Brasil, 1967. Disponível em: < http://www.planalto.gov.br/ccivil_03/constituicao/constituicao67.htm>. Acesso em: 07 jan. 2021. 
Presidência da República. Casa Civil. Subchefia para Assuntos Jurídicos. Constituição da República Federativa do Brasil, 1988. Disponível em: <http://www.planalto.gov.br/ccivil_03/constituicao/constituicao.htm>. Acesso em: 07 jan. 2021.

Presidência da República. Casa Civil. Subchefia para Assuntos Jurídicos. Lei Complementar $n$. 97, de 9 de junho de 1999. Disponível em: < https://www.planalto.gov.br/ccivil_03/leis/lcp/lcp97.htm>. Acesso em: 07 jan. 2021.

SUPREMO TRIBUNAL FEDERAL. ADI 6457 MC/DF - Distrito Federal. Medida cautelar na ação direta de inconstitucionalidade, Relator(a): Min. Luiz Fux, Julgamento: 12/06/2020. Disponível em: < https://jurisprudencia.stf.jus.br/pages/search/despacho1109921/false >. Acesso em: 07 jan. 2021.

CONSTANT, Benjamin. Cours de Politique Constitutionelle, avec introduction e notes. $2^{\mathrm{a}}$. ed. Traduit par Edouard Laboulaye. Paris: Guillamin, 1872.

CITTADINO, Gisele. Pluralismo, direito e justiça distributiva: elementos de filosofia constitucional contemporânea. 5. ed. Andradina: Meraki, 2020.

DWORKIN, Ronald. Direito da liberdade: a leitura moral da Constituição norte-americana. São Paulo: Martins Fontes, 2006.

ECO, Umberto. O fascismo eterno. in Cinco Escritos Morais. Rio de Janeiro: Record, 1998.

EQUADOR. Constitución de la República del Ecuador, 2008. Disponível em: < https://www.asambleanacional.gob.ec/es/noticia/constitucion_kichua>. Acesso em: 10 ago. 2021.

ESTADOS UNIDOS DA AMÉRICA. Constitution of the United States, 1787, Disponível em: < https://www.archives.gov/founding-docs/constitution-transcript>. Acesso em: 07 ago. 2021.

FARIÑAS, Maria José. Supremacismo e fascismo. In: GUAMÁN, Adoración et al (Dirs). Neofascismo. La bestia neoliberal. Titivillus, cap. V, 2020.

FRANCO, André Luiz dos Santos. A sinergia entre a legalidade constitucional e a legitimidade bélica das forças armadas na República Brasileira. Coleção Meira Mattos: revista das ciências militares, n. 24, 2011.

GINSBURG, Tom; HUQ, Aziz. How to save a constitutional democracy. Chicago: University of Chicago Press, 2018.

HAMILTON; MADISON; JAY. O Federalista. Tomo 2. Rio de Janeiro: Typ. Imp. e Const. de J. Villeneuve e Comp., 1840.

HORTA, José Luiz Borges. Dialética do poder moderador: ensaio de uma ontoteleologia do Estado do Brasil. Tese (Titularidade em Teoria do Estado). Belo Horizonte: Universidade Federal de Minas Gerais, 2020.

KELSEN, Hans. Quién debe ser el defensor de la Constitución? Madrid, Tecnos, 1995. LEVITSKY, Steven; ZIBLATT, Daniel. Como as democracias morrem. Rio de Janeiro: Zahar, 2018.

LYNCH, Christian Edward Cyril. Estudos brasileiros: o pensamento político como chave de interpretação do Brasil. Entrevistadores: REGINATTO, Victoria Nicolielo; CARVALHO, João Pedro Braga de; SANTANA, Henrique Ferreira. Revista de Ciências do Estado. Belo Horizonte: v. 6, n. 1, 2021.

MAGALHÃES, Vinicius Cunha. O artigo 48 da Constituição de Weimar e a teoria da soberania e do estado de exceção de Carl Schmitt. Conteúdo Jurídico: Brasília-DF, nov. 2017. 
MAIA NETO, Jacintho. O processo de transformação do exército brasileiro: um estudo sobre os reflexos da era do conhecimento. Coleção Meira Mattos: revista das ciências militares, n. 24, 2011.

A gestão estratégica da defesa: novos tempos, novos desafios. Hemisferio Revista del Colegio Interamericano de Defensa. n. 6, p. 102-122, 2020.

MARIANO, Cynara Monteiro. O debate sobre a separação dos poderes no pensamento constitucional brasileiro. Revista Direitos Fundamentais \& Democracia, Curitiba, v. 4, n. 4, jul. dez 2008.

MARSCHALL, John. Decisões constitucionais. Imprensa nacional, 1908.

MARTINS, Ives Gandra da Silva. Cabe às Forças Armadas moderar os conflitos entre os Poderes. Revista Consultor Jurídico, mai 2020.

MÉXICO. Constitución Política de los Estados Unidos Mexicanos, 1917. Disponível em: < https://constitucion1917.gob.mx/es/Constitucion1917/Constitucion_1917_Facsimilar >. Acesso em: 10 ago. 2021.

MISSIATO, Victor Augusto Ramos. Forças armadas, autonomias e autoritarismo: a atuação das Forças Armadas de Brasil e Chile nas transições rumo à democracia. Revista SulAmericana de Ciência Política, v. 5, n. 1, 2019.

MONTESQUIEU, Charles. Do espírito das leis. Rio de Janeiro: Editora Pimenta de Melo, 1919.

PROENÇA JÚNIOR, Domício. Forças Armadas para quê? Para Isso? Contexto Internacional, v. 33, n. 2, jul. dez, 2011.

PRUDENTE, Wilson. A verdadeira história do direito constitucional no Brasil. V. 1, Niterói: Impetus, 2009.

RAWLS, John. Justiça como equidade. Uma reformulação. São Paulo: Martins Fontes, 2003.

RIBAS, Christina Miranda. Justiça em tempos sombrios: a justiça no pensamento de Hannah Arendt. Ponta Grossa: Toda Palavra, 2019.

ROSAS, Fernando. Salazar e os fascismos. Ensaio breve de história comparada. Lisboa: Tinta da China, 2019.

SAINT-PIERRE, Héctor. As 'novas ameaças' às democracias latino-americanas: uma abordagem teórico-conceitual. In: Eliézer Rizzo de Oliveira. (Org.). Segurança \& Defesa Nacional. Da competição à cooperação regional. $1^{\mathrm{a}}$ ed. São Paulo: Fundação Memorial, p. 59-82, 2007.

SAMPAIO, Rosana Ferreira; MANCINI, Marisa Cotta. Estudos de revisão sistemática: um guia para síntese criteriosa da evidência científica. Revista brasileira de fisioterapia, São Carlos, v. 11, n. 1, p. 83-89, jan./fev. 2007. Disponível em: < http://www.scielo.br/pdf/rbfis/v11n1/12.pdf>. Acesso em: 06 jan. 2021.

SANTA BÁRBARA, Marcelo de Jesus; MEDEIROS FILHO, Oscar. O papel trinitário do Exército Brasileiro: bases de uma força "multitarefas". Coleção Meira Mattos: revista das ciências militares, v. 15, n. 53, p. 147-165, 2021.

SANTOS, Maria Helena de Castro. A nova missão das Forças Armadas latino-americanas no pós-Guerra Fria: o caso do Brasil. Revista Brasileira de Ciências Sociais, v. 19, n. 54, p. 107-128, 2004.

SCHLEGEL, Rogério. Impactos políticos da educação: da aposta no novo cidadão à eleição de Bolsonaro. Revista Educação Social, v. 42, 2001.

SCHMITT, Carl. La Defensa de la Constitución. Madrid: Labor, 1931.

SCHUMPETER, Joseph Alois. Capitalismo, socialismo e democracia. São Paulo: Editora Unesp Digital, 2017. 
SUCCI JÚNIOR, David Paulo. A construção do atual padrão de emprego das Forças Armadas no Brasil. Revista de Iniciação Científica em Relações Internacionais, v. 4, n. 7, p. 875-103, 2016.

SWEET, Alec Stone. Constitutional Courts. In M. Rosenfeld e Andras Sajó (orgs.). Oxford handbook of comparative constitutional law. Oxford University press, 2012.

TELES, Edson. O que resta da ditadura: a exceção brasileira. São Paulo, Boitempo, 2010.

TUSHNET, Mark. Ceticismo sobre o Judicial Review: Uma perspectiva dos Estados Unidos. In: BIGONHA, Antônio Carlos Alpino e MOREIRA, Luiz (org.). Limites do Controle de Constitucionalidade. Coleção ANPR de direito e democracia. Rio de Janeiro: Lumen Juris, 2009.

WALDRON, Jeremy. O judicial review e as condições da democracia. In: BIGONHA, Antônio Carlos Alpino e MOREIRA, Luiz (org.). Limites do controle de constitucionalidade. Coleção ANPR de direito e democracia. Rio de Janeiro: Lumen Juris, p, 243-270, 2009. 
Como citar este artigo: GAGLIARDI, Ricardo. Poder Moderador e a Constituição da República Federativa do Brasil. Revista de Ciências do Estado, Belo Horizonte, v. 6, n. 2, p. $1-35,2021$.

Recebido em 06.07.2021

Publicado em 12.12.2021 